\title{
Marketing and Technology: Role of Technology in Modern Marketing
}

\author{
Dr. Esha Jain ${ }^{1}$, Ashank Yadav ${ }^{2}$ \\ ${ }^{1,2}$ GD Goenka University, Gurgaon, India.
}

\begin{abstract}
The paper is focused over understanding new developments which had influenced modern day marketing. The paper also discusses the concepts of technology which changed the perspective of marketing. When we talk about marketing and role of technology in it, we understand that new marketing concepts have changed the face of $21^{\text {st }}$ century marketing techniques. Now marketing is majorly dependent over technology, emergence of new dimension of marketing is also known as digital marketing. Digital marketing is majorly focused over marketing through digital media devices such as smartphones and computers.
\end{abstract}

Keywords: Information technology, Digital marketing, Digital devices, Technology, Marketing.

\section{Introduction}

This started with the start of marketing, the view of finding new methods of marketing. New techniques through which marketers could target the market. Then came technology, bringing a new dimension to old school marketing and bringing in a revolution. Going by definition technology means" the making, usage, and knowledge of tools, machines, techniques, crafts, systems or methods of organization in order to solve a problem or perform a specific function" whereas the marketing terminologies states technology as a mode or a medium which helps marketer propagate his or her deliverables to the end user. The technology has been dynamic throughout right from television advertisements to internet marketing.

Other name to new age marketing is Digital marketing. Marketing is communicating the value of a product, service or brand to customers, for the purpose of promoting or selling that product, service, or brand. Marketing techniques include choosing target markets through market analysis and market segmentation, as well as understanding consumer behavior and advertising a product's value to the customer. From a societal point of view, marketing is the link between a society's material requirements and its economic patterns of response. Marketing satisfies these needs and wants through exchange processes and building long-term relationships. Marketing blends art and applied science and making use of information technology. Marketing is applied in enterprise and organizations through marketing management. The best outcome of bringing in technology has been innovation. With today's fast innovation stands as a key to success. The products in market have taken the audience by the storm. There are numbers of products lying in the markets to satisfy the needs and desire of the market. The needs be it basic, latent or dreamt has been keeping the marketers on their toes. "Technology is good for Marketing" is a myth though technology does offer lot of advantages but it has lot of negative points to. The advantages of technology do bring in new customers, helps to automate follow up, helps in participating in online decision etc. On the other side the pitfalls include it to be expensive and it is difficult to deal with the brevity of time. The tradeoff between the pros and cons of this has to be weighed properly to take an appropriate step. The usage and introduction of technology at the right time of marketing a product plays a significant part. Introduction phase of any of new entrant be it product or service, when direct marketing is of real importance. Whereas with advent of time for maturity, that is to keep the product alive, technology is instrumental. It adds powers to a monotonous dead product and rejuvenates audience outlook to that product. As technology matures there is hefty expenditure on research. This research does give a birth to new innovation. We address this as technological breakthrough. Marketers strongly believe in the above said. So they constantly put in their conscious efforts and thrive hard to bring in new ideas to market their product. The definition and concepts of marketing have changed for many decades. It has seamlessly transformed from yester years black and white to colored version. The road from door to door marketing to online marketing has covered a great length. The right blend of technology and innovation has been a strong pillar to it.

\section{Impact of Technology In Marketing}

Technology and Communication helps businesses grow and prosper, creates relationships, strengthens the effectiveness of organizations, and allows people to learn about one another. Technologies, such as the Internet, mobile phones, social media, and customer relationship management systems greatly affect the way companies communicate with prospective customers. These new forms of communication are changing the media landscape and the type of messaging strategy organizations use. Many of the consumers and business professionals seek information and connect with other people and businesses from their computers and phones. 
With access to many sources of information and an interest in interactive media, consumers may collect more product information on their own. Work environments are also changing, with more people having virtual offices, texting on their cell phones, or communicating through social media sites such as Facebook, LinkedIn, Pinterest, and Twitter. As the media landscape changes, the money that organizations spend on different types of communication and technology will change as well. Once companies have developed products and services, they must communicate the values and benefits of the offerings to current and potential customers.

Young population today is part of the millennial generation, and it is consumers from this generation who are driving the change toward new communication technologies. A young consumer might opt to get promotions via mobile marketing for example say, from stores on your cell phone as you walk by them or via a mobile gaming device that allows you to connect to the Web. Likewise, advertisements on Facebook are popular as businesses continue to utilize more social media. Traditional media such as magazines, newspapers, television compete with media such as the Internet, texting, mobile phones, social media, user-generated content such as blogs, and YouTube as well as out-of-home advertising such as billboards and movable promotions. Therefore, all forms of marketing media have been forced to come up with new innovations to remain relevant. With high consumer expectations and an explosion in engagement devices and channels, marketers today are faced with a sprawling matrix of disconnected figures to make sense of them. Some tools today provide a more consolidated view of figures, but still around $71 \%$ of Chief Marketing Officers (CMOs) feel unprepared for the data explosion they face. Collecting metrics today means going beyond tracking the transaction and business objectives. In order to leverage metrics strategically to create loyal and engaged clients, businesses need to look at creating consolidated, personal views of their customers that span channels. They need metrics that can come together to help paint a picture of the end-to-end client relationship and show how to better target messaging to drive engagement. Marketers need to find a way to break down the silos and connect the data sources. Only then can they get a complete view of client interaction and transactions and leverage this data to build strong relationships.

\section{Tools of Modern Marketing}

Modern marketing uses Digital marketing. It could be explained as a marketing that makes use of electronic devices such as personal computers, smartphones, and cellphones, tablets Television sets TV and game consoles to engage with stakeholders. A component of Digital marketing is Digital Brand Engagement. Digital marketing applies technologies or platforms such as websites, e-mail, apps and social networks. Digital Marketing can be through Non-internet channels also like TV, Radio, SMS, or through Internet channels like Social Media, E-mails ads, Banner ads. Social Media Marketing is a component of digital marketing. Many organizations use a combination of traditional and digital marketing channels though however, digital marketing is becoming more popular with marketers as it allows them to target and track many aspects including their Return on Investment (ROI) more accurately compared to other traditional marketing channels. Digital Marketing is the use of digital channels to promote or market products and services to consumers and businesses. A transformation of marketing is underway as we spend more time on our mobiles, tablets and laptops. The challenge for brands is to connect with customers through all these devices in real time and create campaigns that work across social media, display advertising and e-commerce.

The real-time conversations brands have with people as they interact with websites and mobile apps has changed the nature of marketing. The modern-day marketing department needs to combine the creative side of the discipline by using powerful narratives to tap into people's wishes and aspirations with the technical side of data, digital engineering and analytics. The two areas do not always sit easily together. Getting creative marketers to work alongside technical staff can be a huge challenge. Three areas of marketing which have been transformed by digital are the speed, relevance and reach of campaigns. Digital marketing has also greatly increased relevancy. Messages can be targeted with a laser focus to very specific groups offering them relevant content. The reach of campaigns has also increased greatly. With so many different ways that customers access media, whether through Facebook, YouTube, news websites, via mobile or tablet apps, a strong idea can quickly gain huge scale. Marketers need to update their skills in order to make the most of these fast-moving, and highly relevant campaigns through digital. They need to work closely with data specialists, web developers and social media professionals. The marketer of the future needs to combine marketing and creative skills with an understanding of real-time technology. Just as marketers need to become savvier about technology, data and analytics, so the technically minded staff on the digital side have to get more creative and they are rising to this challenge. A vital quality for marketers in the fast-changing digital environment is curiosity, rather than any specific technical knowledge. For brands to work effectively together in the digital world, chief marketing officers and chief information officers work in unison. But this is hard to achieve for many organizations and the two sides can end up in conflict. Pure digital players such as Net-a-Porter that have always been digital are structured for the digital age. Looking for a career in marketing must be prepared to bring together the magic of marketing and the science of technology to create powerful and relevant marketing campaigns. Today's 
connected consumers are using smartphones, iPads, laptops and even glasses and watches to access content. As a result, marketing departments need to provide compelling campaigns across these different devices and become proficient in using technology. Marketers work closely with IT departments and technologists. They understand the processes behind developing websites, handling data and running social media campaigns. The panel discussed how marketers could develop the skills to enable them to work hand in hand with technologists while retaining their creativity, flair and intuition.

\section{Marketing Technology: Past And Future}

There's no denying that technology had changed the way that global citizens receive, interpret and react to information. With the rise of the internet at the turn of the twenty-first century, and the rapid evolution of devices that allow quick and easy access to its millions of portals, consumers are finding new ways to interact with companies and with products. Given these new forms of buyer seller interactions, many professionals and individuals alike now believe that the information age, facilitated by evolving technologies, has redefined the role of marketing. The role of marketing has historically changed with time. Marketing's role shifted to developing and managing customer relationships. Today, more than decade after this new role was adopted, marketers are still engaged in building these relationships. Though the role of marketing has not changed due to technology, the power dynamic in buyer seller relationships, corporate attitudes toward the marketing function and marketing approaches have all been inextricably altered by the rapid evolution of technology.

The rise of the internet has been the single most detrimental catalyst in the change of the power dynamic from marketers to consumers. Through the use of the internet, consumers have gained access to multitudes of data from around the world data that is timeless, critical and verifiable. With just a click of a button consumers can gain meaningful insights about companies and their products. They can compare products, find lower prices, read reviews and even communicate with other users about product quality and buyer satisfaction. Even further, internet users are not just using content, they are creating and sharing with others, allowing for unprecedented transfers of information and knowledge. With the explosion of social media, such as Facebook, Twitter, Tumblr, Instagram and more, consumers can access direct feedback about products both good and bad from their connections. On this day, a blog or video created by a dissatisfied customer can become viral in a matter of hours. Even more impactful than the action of the post is the reaction it elicits in those it encounters. This shift is consequently eliminating the notion of brand supremacy and brand loyalty. As consumers seek value at lower costs, brands are fast becoming commodities, posing challenges to the modern marketer. Today marketers ensure brand integrity. Since simply creating a product and pushing it upon customers no longer works. Marketing is now forced to listen to customers and find ways of converting interactions into personalized, value-laden products that are affordable and better than that of competitors. It must also find ways of infusing its products with best service that can win digital brand ambassadors, who can broadcast brand value to their connections. Whatever the approach, the reality remains that companies are no longer in charge of the communication process, their brand message and even their pricing models at times. Technology has given way to the rise of the conscious consumer.

Marketing had been labeled as one of the four key functional areas of a business. However with marketing's role changing in the late 1990's to building customer relationships, there has been a subsequent change in the way the overall function is regarded internally within corporations. Today, marketing is recognized as the glue that binds organizations together. It is marketing's sales projections that assist operations in determining production levels and finance in planning budgets. It is the very same marketing, whose predictive analytics of customer trends and needs that helps research and development determine new projects for product development. Integral to this cross-functional view is the belief that marketing has become everyone's business. With increased access to information encouraged by the use of mobile digital technologies, consumers are no longer waiting for marketers to reach out to them. Today, consumers interested in seeking additional information may reach out to a company, both online and offline. The individuals and systems with which these consumers engage are all touch points. They provide valid sources of information that help companies create dynamic customer profiles and typesets. These can in-turn be used to develop personalized messages and products, which companies can later market to these very customers. Two drivers are key at play here. The first is that consumers no longer differentiate between customer service and product. Just as technology has integrated the world, placing it at every consumer's finger tips, so too have their beliefs of customer service, product, marketing and business functions become integrated as one. Consumers will create touch points with every aspect of the business, which means these interfaces must be prepared to engage, that is, market their products and themselves. Herein lies the second driver. Because marketing's role is to build customer relationships, and because touch points do not only happen between the marketing department and customers, other departments must also be infused with the marketing function. With the increasing use of Customer Relationship Management systems within companies that help to integrate and transform the information from these touch points, it to dynamic strategies, it has become even more important for marketing 
to be diffused throughout every aspect of a business. Companies, such as Starbucks and Zappos that have embraced this new marketing concept have lived to experience tremendous success in this highly transparent world. Understanding that the power of the message no longer laid in the medium, but rather in the ways in which the medium is used, most marketers began rebranding their business, focusing their resources on building interactive relationships with consumers in online communities rather than pushing media campaigns. Well for starters, marketers are no longer guided by the adage, "a superior product will sell itself." Understanding how the internet has facilitated globalization, and the ease at which customers can source and purchase products from anywhere in the world, marketers have become more robust, strategically positioning themselves wherever their customers are located in the digital sphere. At these new touch points, the astute marketer listens to his customer, gathers enriched, personalized data, which he manipulates to provide valuable solutions, not push his product unto the customer. Today's marketer understands that content is king and that to survive, marketers must become multi-channel publishers as well. As users continuously search for fresh information, marketers are now faced with the challenge of continuously feeding that need and doing so using the right format, scope and tone. Developing open-source content is critical to this strategy, as is finding ways to ensure that the messages are syndicated and integrated with other sites through links. Websites are now filled with blogs, through which marketers offer insights not necessarily about their products or services but more so about their customers most pressing concerns - all in the hopes of nurturing the buyer seller relationship and building brand loyalty. Understanding the perceived value that customers ascribe to personalized messages, the practice of mass marketing has taken a back seat, to diversified advertising that is rooted in the notion that quality customer relationships translate to greater returns than just mere relationship. Because of the ease and frequency of distribution of user and marketer generated content, marketers are also "brand vigilantes," forced to keep a watchful eye for brand defamation online. Just as one good review written by a customer, which is shared with connections in an online community can boost a brand's reputation and customer base, so too can negative feedback offered by users.

By far the most compelling change of the approach to the marketing function since the turn of the century has been the shift from Outbound Marketing to Inbound Marketing. Building from the experiences learned from doing business, businesses have come to recognize the overwhelming advantages of pulling customers toward their product, rather than pushing their products toward their customers. Outbound Marketing, defined by its insistence on bombarding consumers with messages through print, radio and television advertisements, as well as those annoying telemarketing and spam email messages, are not only costly, but are simply no longer effective. The realization of the inability of traditional marketing to cut it on its own has given way to the pull marketing phenomena. This new strategy provides tremendous benefits to businesses. Inbound Marketing pulls customers toward a brand by supplying value laden content, such as white papers, eBooks, info graphics and more that allow marketers to earn their way into customers inner circles. From here marketers can massage the needs of their customers and gain privileged, personal information that they can use to redefine and specify their market segments, determine valuable leads and create personalized messages and products. As content is fed through sites like Twitter, Facebook and news aggregators, such as Reddit.com and Digg.com, its reach can multiply making its message viral. With search engines being the go to tool for consumers seeking to clarify or gather information, marketing is also charged with the responsibility of ensuring that their content is not only customer focused, but search engine optimized by its use of specific ad words. Through social media and the internet, marketing's attitude toward the development of advertisements and promotions has also changed. Before the change in approach, marketing departments depended on inside creativity and intellect, or that of outsourced hires, to help conceptualize advertising campaigns. With crowd sourcing, companies can continue strengthening their customer relationships and achieve winning advertisements at a cheaper rates. This brings us to the issue of cost, and the ways in which this new marketing approach affects the bottom-line. Unlike traditional Outbound Marketing, Inbound Marketing, because of its use of digital technologies that allow for greater reach and specificity, offers greater, quantifiable returns, at cheaper costs. Inbound Marketing reportedly cost $62 \%$ less per lead than outbound marketing. The use of business intelligence, predictive analytics and Customer Relationship Management systems and other software applications and programs are all inherent in this new marketing approach. These technologies allow companies to quickly sort, analyze and translate the variety of data they access from the increasing touch points with their customers. Together with the evolution of the internet and digital devices that allow quick reliable access to its portals, the marketing approach, not its role, will continue to evolve. In the coming years, it won't be strange to see marketing's function becoming more diluted with information technology, giving birth to marketing-tech teams. CMOs and CIOs will collaborate on greater projects, with the former dropping more budget bucks on information technology than the latter. Mankind's fascination with mobile technologies, configured with GPS, 4G and Wi-Fi capabilities, combined with their thirst for information on-the-go will channel attention away from traditional media outlets to handheld devices. With the need to be where the customer is, marketing will be charged with the responsibility of not only creating content, but formatting it to meet the mobile platform. This however, will not 
mean the death of traditional Outbound Marketing and thus the historical function of marketing. Because there will always be differentiated customers; because old systems can be repurposed; and because even popular Inbound Marketing champs Hub Spot now admit to using a mixture of both Inbound and Outbound Marketing, believing marketing's function will be split, whether evenly or unevenly, amongst the two approaches. One thing is certain that Marketing's role of developing quality customer relationships will force its function to positively correlate with the changing behaviors of its customers. Their behaviors and habits whether driven by technology, globalization, or other trends, will direct the continuous evolution of the marketing function. Technology has always changed how marketing works. What is different today is the unprecedented rate of change in the both the development of marketing tools and the escalation of expectations for better experiences from customers.

\section{Conclusion}

When understanding the developments of new era marketing, we understand that the new age marketers have worked hard to bring marketing close to our day to day life and the gap is filling every second. Technology is a major factor and tool for the marketers to reach the masses and the target audience. With amalgamation of technology and marketing, industries had reaped beautiful fruits which could have been never achieved. No one had ever thought that apart from print media there could be any other method of marketing back past few decades. Marketing and its concepts are changing and they will keep on changing undoubtedly, the major part which cannot be denied or neglected is the emergence of technology as a new branch of marketing which is known as "Digital Marketing". Finally, marketing today and past ten years, saw a significant change and that change is technology.

\section{References}

[1]. Boundless. "Impact of Technology on Marketing." Boundless Marketing. Boundless, 19 Mar. 2015. Retrieved 19 Mar. 2015 from https://www.boundless.com/marketing/textbooks/boundless-marketing-textbook/the-marketing-environment-3/technology32/impact-of-technology-on-marketing-170-7298/

[2]. Retrieved 11 Mar. 2015 from http://www.mbaskool.com/business-articles/marketing/4330-role-of-technology-in-marketing.html

[3]. Retrieved 12 Mar. 2015 from http://www.theguardian.com/media-network/media-network-blog/2014/sep/29/technology-changingmarketing-digital-media

[4]. Retrieved 15 Mar. 2015 from http://www.forbes.com/sites/johnellett/2014/09/30/technology-is-changing-the-future-of-marketingagain/

[5]. Retrieved 16 Mar. 2015 from http://www.mba-exchange.com/candidates/mba-knowledge-article.php?kpo=285

[6]. Retrieved 19 Mar. 2015 from https://econsultancy.com/blog/65406-the-role-of-the-chief-marketing-technologist/

[7]. "The future has arrived with digital marketing". Retrieved 2015-03-11.

[8]. Clark, Dorie (11 November 2012), The End of the Expert: Why No One in Marketing Knows What They're Doing, Forbes, archived from the original on 4 November 2013

[9]. "Ad agency joins up with AOL for marketing surveys". Retrieved 2015-03-11.

[10]. Kates, Matthew (17 April 2013), Making digital and traditional marketing work together, Econsultancy, archived from the original on 25 November 2013

[11]. Retrieved 19 Mar. 2015 from http://www.iccwbo.org/advocacy-codes-and-rules/areas-of-work/marketing-and-advertising/digitalmarketing-communication/

[12]. Brinkley, Claire (18 October 2012), Digital marketing is growing in Australia, but so is the skills gap, Econsultancy, archived from the original on 21 October 2012

[13]. E Marketer (25 September 2013), Worldwide Ad Growth Buoyed by Digital, Mobile Adoption, eMarketer, archived from the original on 12 November 2013

[14]. Retrieved 19 Mar. 2015 from http://www.iccwbo.org/advocacy-codes-and-rules/areas-of-work/marketing-and-advertising/digitalmarketing-communication/

[15]. Retrieved 11 Mar. 2015 from Google, Trends. "Google Trends". Google Inc. Retrieved 9 February 2014.

[16]. Retrieved 08 Mar. 2015 from http://www.codescentre.com/media/1010/654-oba-resource-guide_final.pdf

[17]. Retrieved 07 Mar. 2015 from http://www.hcltech.com/sites/default/files/whitepaper_-_collaborating_with_digital_agency_0.pdf

[18]. Retrieved 14 Mar. 2015 from http://www.codescentre.com/icc-code/digital-interactive-media.aspx 